\title{
キュウリホモプシス根腐病に対するクロルピクリンくん蒸剤マルチ畦内処理と 抵抗性台木クロダネカボチャの併用による防除効果
}

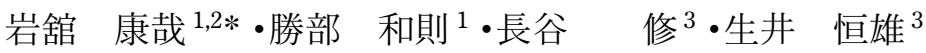

\begin{abstract}
IWADATE, Y. ${ }^{1,2 *}$, KATSUBE, K. ${ }^{1}$, HASE, S. ${ }^{3}$ and NAMAI, T. ${ }^{3}$ (2011). Integrated control of cucumber black root rot using chloropicrin fumigation in polyethylene-mulched beds of resistant rootstock of Cucurbita ficifolia. Jpn. J. Phytopathol. 77: 278-286.

Black root rot of cucumber (Cucumis sativus) caused by Phomopsis sclerotioides is a serious greenhouse disease in many countries. Since 2001, the disease has been observed on outdoor-cultivated cucumber grafted on pumpkin rootstock in the Tohoku region of Japan, causing severe economic losses. We sought to establish control measures against black root rot of cucumber grafted on pumpkin rootstock caused by $P$. sclerotioides in outdoor culture in the Tohoku region of Japan. Soil fumigants chloropicrin (298.5 L a.i./ ha), dazomet (294 kg a.i./ha), metham sodium (180 L a.i./ha), and fluazinam (15 kg a.i./ha) were evaluated for efficacy in naturally infested fields. Because it reduced sudden wilting, chloropicrin was selected for subsequent experiments to develop effective control. Partial fumigation (injection into polyethylene-mulched beds) gave adequate control, better than overall fumigation in fields. Partial fumigation significantly reduced sudden wilt incidence by $77 \%$ and $100 \%$ compared to untreated plots, and overall fumigation yielded $54 \%$ and $100 \%$ reduction in two experiments. For chloropicrin injection into polyethylene-mulched beds, a 90 -cm width of the beds was better than the common practice of $60-\mathrm{cm}$ width. Since the $90-\mathrm{cm}$ width disinfested a wide area, we concluded that control was high (90-cm width significantly reduced sudden wilt incidence by $95 \%$ and $100 \%$ compared to untreated plots, and 60 -cm width yielded $70 \%$ and $82 \%$ reduction in two experiments). However, these treatments did not completely control sudden wilt. Combining these treatments with the use of resistant rootstock C. ficifolia, which by itself suppressed disease from $56 \%$ to $100 \%$ in three experiments, reliably decreased the incidence of sudden wilt by $100 \%$ reduction in three experiments compared to the untreated plots. The efficacy of each control measure alone varied, so integrated methods are preferable.
\end{abstract}

(Received April 28, 2011; Accepted August 18, 2011)

Key words: chloropicrin, Cucumis sativus, cucurbit, Phomopsis sclerotioides, soil fumigation, sudden wilt

\section{緒言}

ウリ科野菜に急性萎调症状を引き起こすホモプシス根腐病 (Phomopsis black root rot of cucurbit) は, Phomopsis sclerotioides Kesteren によって引き起こされる土㙵伝染性の難防除病害 である. 本病は 1964 年にオランダの施設栽培キュウリで初 確認された（van Kesteren, 1967）のち，アジア，ヨーロッパ の多くの国々のキュウリ栽培地域に执いて発生が認められ, 多大な被害を及湆している (Bruton, 1996)。本邦では, 1983 年に埼玉県でカボチャ台キュウリの萎调症状の原因として
初確認された（橋本・吉野, 1985)。その後, 国内の発生地 域は拡大し, これまでに関東, 東北の複数県のほか島根県な どのキュウリ，スイカ, カボチャ, メロン産地で発生が報告 されている（永坂・門田，2008）。キュウリ栽培に扔ける本 病の発生は, 当初は施設栽培に限られていたものの, 2001 年 には福島県, 2002 年には岩手県の露地夏秋キュウリで発生が 確認された（堀越ら，2003; 岩舘ら，2006）。国内で分離され た病原菌については，永らく未同定であったが，分生子形成 の確認や分子生物学的解析から, P. sclerotioides であることが 明らかとなった（Shishido et al., 2006）.

1 岩手県農業研究センター（テ 024-0003 岩手県北上市成田 20-1） Iwate Agricultural Research Center, 20-1 Narita, Kitakami, Iwate 0240003, Japan

2 岩手大学大学院連合農学研究科（章 020-8550 岩手県盛岡市上田 3-18-8） The United Graduate School of Agricultural Sciences, Iwate University, 3-18-8 Ueda, Morioka, Iwate 020-8550, Japan

3 山形大学農学部（干 997-8555 山形県鶴岡市若葉町 1-23） Faculty of Agriculture, Yamagata University, 1-23 Wakaba-machi, Tsuruoka, Yamagata 997-8555, Japan

* Corresponding author (E-mail: y-iwadate@pref.iwate.jp) 
岩手県では，夏期の冷涼な気候を利用した露地夏秋作型 のキュウリ栽培が盛んであり, 栽培面積は 321 ha (2009 年) におよび，夏秋キュウリの都道府県別の収穫量割合は全国 第 4 位（2009 年）となっている. 本県での本病の発生地域は, 2002 年の初確認以来, 年々拡大し 2010 年現在, 県中部から 県南部を中心として 15 市町で発生が確認され, 今後さらな る発生地域の拡大やキュウリ以外のウリ科野菜での被害発 生が懸念されている.

本病は, 露地夏秋作型のキュウリの場合, 収穫最盛期に向 から梅雨から梅雨明䫉に急性萎凋症状を示し, 最終的には 枯死に至る. 本病に感染すると, 収穫最盛期に萎调・枯死す ることから経済的損失は極めて大きい. 加えて, 本病の発生 によりキュウリ農家が受ける精神的影響も深刻で, 栽培意欲 の低下につながり, キュウリ栽培面積減少の一因ともなって いる（岩舘ら，2010）。本病の被害は，低温期の定植で助長さ れ（宍戸，2006），記録的な冷害年となった 2003 年には，福 島県抢よび岩手県の主要なキュウリ産地で多発し, 両県での 被害推定額は約 10 億円にまで達した（永坂・門田，2010）.

本病原菌は, 高温耐性が低いことから, 関東以南の施設栽 培キュウリや露地のトンネル栽培メロンでは, 夏期の太陽熱 消毒や太陽熱消毒と土壤消毒剤の併用による防除法が有効 とされている（橋本・吉野, 1985; 小林ら，1997）. しかし, 夏秋期が栽培期間となる東北地方の露地夏秋作型のキュウ リ産地では, 定植前の低地温期に土壌消毒せざるを得ないた め, 太陽熱消毒期間を設けることは難しく, 防除効果も期待 できない。このように，東北地方の露地夏秋作型のキュウリ 産地では, 本病による萎调症状の発生リスクが高い一方で, 有効な防除対策が明らかにされていないことから, 実用可能 な土壌消毒技術の確立が望まれていた. 土壌消毒以外の防除 対策としては，抵抗性台木の利用があげられるが，完全な抵 抗性を有する台木は確認されていない（宾戸，2006）。一方 で，クロダネカボチャ（Cucurbita ficifolia Bouché）やトウガ ン (Benincasa hispida Thunb.) は，完全な抵抗性を示すもの ではないがキュウリ用の一般的な台木品種と比較すると 発病抑制効果が認められる（van Kesteren, 1967; Wiggell and Simpson, 1969; 山口・岩舘, 2009). このため, これらの抵抗 性台木と土䁃消毒を併用することで被害を軽減できる可能 性が示唆されている（堀越ら, 2003 ; 岩舘ら，2006）.

そこで, 本研究は, おもに露地夏秋作型のキュウリ産地を 対象とした実用的なホモプシス根腐病防除技術の確立を目 的に, 本病防除に有効な土壤消毒剂を選抜するとともに, 効 果的な処理手法を検討した. あわせて土壌消毒と抵抗性台木 の併用による防除効果について検討したので報告する.

\section{材料および方法}

キュウリホモプシス根腐病に対する有効薬剂の選抜 2005 年に第 1 表に示す土壌消毒剤 4 剂を供試し, 防除効果を 比較した. 試験はキュウリホモプシス根腐病が自然発病する 岩手県北上市の露地夏秋作型のキュウリ連作圃場に扣いて 実施した. ダゾメット粉粒剂（商品名：バスアミド微粒剂）, フルアジナム粉剤（商品名：フロンサイド粉剂）は，試験区 に均一に手散布し，ロータリーによって混和処理した. クロ ルピクリンくん蒸剤（商品名：クロールピクリン），カーバ ムナトリウム塩液剤（商品名：キルパー）は，手動式灌注機 （共立，HF-4XA）を用いて規定量を注入処理した。いずれの 薬剂も，処理後ただちにポリエチレンフィルムで被覆した. 各薬剂ともに試験区全面に処理し，定植前には被覆を除去 し，ガス抜きを兼ねた畦立て耕起を行った，なお，処理薬量 は各薬剤の使用基準に従い常用処理量とした（第 1 表）。供試 キュウリ品種は，“Vロード’ (Cucumis sativus L., タキイ種 苗）とし，台木は ‘ひかりパワー’ (Cucurbita moschata (Duch. ex Lam.) Duch. ex Poir.; ブルームレス台木，ときわ研究場）と した. 試験区は，無処理では 1 区 18 株の 2 反復，各薬剂処 理区は 1 区 9 株の 3 反復とした. 各薬剤処理区に打ける 1 区 あたりの薬剤処理面積は $11.7 \mathrm{~m}^{2}(1.95 \mathrm{~m} \times 6 \mathrm{~m})$ とした.

クロルピクリンくん蒸剤のマルチ畦内処理と全面処理の 防除効果 2005 年および 2006 年にマルチ畦内処理と全面処 理の防除効果を比較した。試験はキュウリホモプシス根腐病 が自然発病する岩手県北上市の露地夏秋作型のキュウリ連 作圃場において実施した. クロルピクリンくん蒸剤マルチ畦 内処理（以下，マルチ畔内処理）では，供試薬剤をマルチ畦 内土壌消毒機（佐野アタッチ研究所, P3F1B-MK) により,

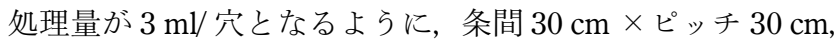
注入深 $15 \mathrm{~cm}$ として千鳥状に 1 晆あたり 3 条灌注処理した. マルチ畘内処理では，土壌消毒時に畦立ておよびマルチ被覆 を同時に実施した．マルチ畦内処理後は定植直前までマルチ 被覆により密閉し，ガス抜き耕起は行わなかった．全面処理 では，供試薬剂を手動式灌注機（共立，HF-4XA）により，条 間 $30 \mathrm{~cm} \times$ ピッチ $30 \mathrm{~cm}$ とし, 注入深 $15 \mathrm{~cm}$ で格子状に灌注 処理した，定植前には被覆を除去し，ガス抜きを兼ねた畦立 て耕起を行った。処理薬量は, マルチ畘内処理, 全面処理と もに $3 \mathrm{ml} /$ 穴 $(30 \mathrm{l} / 10 \mathrm{a})$ とした. 試験畦幅は $60 \mathrm{~cm}$ とした. 供試キュウリ品種は，2005 年は ‘V ロード’，2006 年は“夏 ばやし’とし，台木は 2 か年ともに ‘ひからパー’とした. 2005 年の試験では，全面処理は 1 区 9 株の 3 反復，その他 は 1 区 18 株の 2 反復とした。全面処理に打ける薬剤処理面 積は, 1 区 $15 \mathrm{~m}^{2}(2 \mathrm{~m} \times 7.5 \mathrm{~m})$, マルチ睢内処理に打ける薬 
剂処理面積は, 1 区 $9 \mathrm{~m}^{2}(0.6 \mathrm{~m} \times 15 \mathrm{~m})$ とした. 2006 年の 試験では, いずれも 1 区 18 株の 2 反復とした. 全面処理に 扮ける薬剂処理面積は, 1 区 $30 \mathrm{~m}^{2}(2 \mathrm{~m} \times 15 \mathrm{~m})$, マルチ畦 内処理に打注薬剤処理面積は, 1 区 $9 \mathrm{~m}^{2}(0.6 \mathrm{~m} \times 15 \mathrm{~m})$ と した.

クロルピクリンくん蒸剂マルチ畦内処理時の消毒畦幅と 防除効果 マルチ眭内処理時の消毒畦幅と防除効果につい て, 2005 年抢よび 2007 年の 2 か年検討した. 2005 年の試験 は岩手県花巻市，2007 年は岩手県北上市に打いて実施した. いずれの試験圃場もキュウリホモプシス根腐病が自然発病 する露地夏秋作型のキュウリ連作圃場とした. 試験畦幅は, 慣行畦幅である $60 \mathrm{~cm}(950 \mathrm{~mm}$ 幅マルチ相当）と，それよ りやや広い $90 \mathrm{~cm} （ 1350 \mathrm{~mm}$ 幅マルチ相当）とした。また， 2007 年は, 通常栽培では用いられない畦幅 $30 \mathrm{~cm}$ についても 検討した. 作畦および薬剂処理はマルチ畦内土壌消毒機（佐 野アタッチ研究所，P3F1B-MK）を用いた．供試薬剤はクロ ルピクリンくん蒸剤とした. 供試薬剤は, 消毒畦幅 $90 \mathrm{~cm}$ で は $30 \mathrm{~cm}$ 間隔の 3 条処理, 消毒畦幅 $60 \mathrm{~cm}$ では $30 \mathrm{~cm}$ 間隔の 2 条処理, 消毒畦幅 $30 \mathrm{~cm}$ では畦中央部の 1 条処理とした. 処理薬量は, いずれの消毒畦幅においても $3 \mathrm{ml} /$ 穴 (30 l/10a) とした，供試キュウリ品種は，2005 年は 'V ロード”， 2007 年は“夏ばやし’とし，台木は 2 か年ともに ‘ひから゚ワー とした. 2005 年の試験では, 消毒畦幅 $90 \mathrm{~cm}$ および $60 \mathrm{~cm}$ は 1 区 $41 \sim 42$ 株の 3 反復, 無処理は 50 株の 2 反復とした. 消 毒畦幅 $90 \mathrm{~cm}$ に扮ける薬剤処理面積は, 1 区 $30.6 \mathrm{~m}^{2}(0.9 \mathrm{~m}$ $\times 34 \mathrm{~m})$ ，消毒畦幅 $60 \mathrm{~cm}$ に抢ける薬剂処理面積は，1区 $20.4 \mathrm{~m}^{2}(0.6 \mathrm{~m} \times 34 \mathrm{~m})$ とした. 2007 年の試験では, いず れも 1 区 18 株の 2 反復とした. 消毒畦幅 $90 \mathrm{~cm}$ に抢ける薬 剂処理面積は, 1 区 $13.5 \mathrm{~m}^{2}(0.9 \mathrm{~m} \times 15 \mathrm{~m})$, 消毒畦幅 $60 \mathrm{~cm}$ に打沙薬剤処理面積は, 1 区 $9 \mathrm{~m}^{2}(0.6 \mathrm{~m} \times 15 \mathrm{~m})$ とした.

クロルピクリンくん蒸剤マルチ畦内処理および抵抗性台 木の併用による防除効果 マルチ畘内処理と抵抗性台木の 併用による防除効果について 2005 年から 2007 年の 3 か年検 討した. 試験はキュウリホモプシス根腐病が自然発病する岩 手県北上市の露地夏秋作型のキュウリ連作圃場に扔いて実 施した．抵抗性台木としてクロダネカボチャ台木 “黒ダネ南 瓜’ (C. ficifolia, サカタのタネ) を, 抵抗性が弱い慣行台木 として ひかりパワー’を供試した. 供試薬剤は, マルチ畦 内土壌消毒機（佐野アタッチ研究所, P3F1B-MK）により, 処理薬量が $3 \mathrm{ml} /$ 穴 (30 1/10a) となるように, 条間 $30 \mathrm{~cm} \times$ ピッチ $30 \mathrm{~cm}$, 注入深 $15 \mathrm{~cm}$ として千鳥状に 1 晆あたり 3 条 灌注処理した. 試験畔幅は, 2005 年および 2006 年は $60 \mathrm{~cm}$, 2007 年は $90 \mathrm{~cm}$ とした。供試キュウリ品種は, 2005 年は $\mathrm{V}$
ロード’，2006 年拉よび 2007 年は“夏ばやし’とした. 2005 年の試験では, ‘マルチ畦内処理・黒ダネ南瓜’は 1 区 9 株 の 3 反復，その他は 1 区 18 株の 2 反復とした。 マルチ畦内 処理・黒ダネ南瓜”に打ける薬剤処理面積は 1 区 $4.5 \mathrm{~m}^{2}(0.6 \mathrm{~m}$ $\times 7.5 \mathrm{~m})$ とし，‘マルチ畦内処理・ひかりパワー’に打ける 薬剂処理面積は 1 区 $9 \mathrm{~m}^{2}(0.6 \mathrm{~m} \times 15 \mathrm{~m})$ とした。 2006 年 の試験では，1区 18 株の 2 反復とした。 ‘マルチ畦内処理・ 黒ダネ南瓜’, ‘マルチ畦内処理・ひかりパワー'に打称 剤処理面積は 1 区 $9 \mathrm{~m}^{2}(0.6 \mathrm{~m} \times 15 \mathrm{~m})$ とした. 2007 年の 試験では, 1 区 18 株の 2 反復とした. マルチ畦内処理・黒ダ ネ南瓜’, ‘マルチ畦内処理・ひかりパワー'に拈ける薬剤処 理面積は 1 区 $13.5 \mathrm{~m}^{2}(0.9 \mathrm{~m} \times 15 \mathrm{~m})$ とした.

調査方法 夏秋キュウリの収穫盛期にあたる 8 月上旬〜下 旬に各試験区の萎调株の発生状況を調査し, 萎调株率を求め た，全身に萎调症状を呈する株，および萎调症状の発生によ り枯死した株を萎调株と判定した。また，9月上旬〜下旬に 各試験区から抜根し, 洗浄後, 根部発病状況について下記の 指数別に調査し, 平均発病指数を算出した.

指 数 $0:$ 根の褐変が認められない

$1:$ 根の $10 \%$ 未満が褐変

$2:$ 根の $10 \%$ 以上 $50 \%$ 未満が褐変

$3:$ 根の $50 \%$ 以上が褐変 $4:$ 枯死

本病に対する防除効果を評価するため，調査で得られた萎 调株率, 根部発病指数について次式により防除価を算出した.

萎调株率の防除価 $=$ （無処理区の萎调株率－処理区の萎调 株率）／無処理区の萎调株率 $\times 100$

根部発病指数の防除価 $=($ 無処理区の平均発病指数 - 処理 区の平均発病指数）／無処理区の平均発病指数 $\times 100$

統計処理 萎调株率の多重比較検定については, Ryan 法 を用いた（田代，2007）。根部発病指数の多重比較検定につ いては, Kruskal-Wallis 検定の後に Steel-Dwass 法を用いた.

マルチ畦内処理の有効性の評価では, 使用台木 ひかりパ ワー’を用いたマルチ畦内処理の消毒畦幅 $60 \mathrm{~cm}$ 打よび $90 \mathrm{~cm}$ とした試験成績の萎调株率について, メタアナリシス （丹後, 2002）により，無処理に対する防除効果を評価した. すなわち, マルチ畦内処理の消毒畦幅 $60 \mathrm{~cm}$ とした第 2 表, 第 3 表に示す 2005-1，2006-1，2005-2，2007-1 の 4 試験事例 および，消毒畦幅 $90 \mathrm{~cm}$ とした第 3 表，第 4 表に示す 20052，2007-1，2007-2の3 試験事例を解析に用いた. メタアナ リシスは, DerSimonian-Laird method により, 統計ソフトウェ アStatsDirect Version 2.7.8（StatsDirect Ltd）を用い，マルチ 畦内処理と無処理の萎调株率の割合（リスク比）を求めて各 消毒畦幅について防除効果を評価した. 


\section{結果}

\section{キュウリホモプシス根腐病に対する有効薬剤の選抜}

第 1 表に各種土畩消毒剂のキュウリホモプシス根腐病に対 する防除効果を示した. 無処理の萎调株率が $25.0 \%$ と多発生 条件下での検討となった．供試した 4 薬剤の中でクロルピク リンくん蒸剤は, 萎调株の発生がみられず（防除価 100), 根 部発病指数も 0.26 (同 84）と低かった. このことから, クロ ルピクリンくん蒸剤は本病防除薬剤として有望と判断し, 以 下の試験では本剤を用いた。

クロルピクリンくん蒸阂のマルチ畦内処理と全面処理の 防除効果

第 2 表にマルチ畦内処理と全面処理の防除効果を示した.
無処理の萎调株率が 2005 年では 25.0\%，2006 年では $36.1 \%$ といずれの年次も多発生条件下での検討となった。、ルチ畦 内処理と全面処理を比較すると, 2005 年は, 萎调株の発生お よび根部の発病ともに有意差は認められなかった。 2006 年 は，萎调株の発生では統計的な有意差は認められなかったも のの, 根部の発病はマルチ畦内処理で有意に少なかった．萎 调株率の防除価でみると, 2005 年はマルチ畦内処理, 全面処 理いずれも防除価 100 であったが，2006 年はマルチ畦内処 理が優った．根部発病指数の防除価でみると，2 か年いずれ もマルチ畦内処理は, 全面処理に優った.

クロルピクリンくん蒸剤マルチ畦内処理の消毒畦幅と防 除効果

第 3 表にマルチ畦内処理に抢ける消毒畦幅と防除効果を示

第 1 表 キュウリホモプシス根腐病に対する各種土壌消毒剂の防除効果

\begin{tabular}{|c|c|c|c|c|}
\hline $\begin{array}{c}\text { 供試薬剂 } \\
\text { (有効成分：含有割合） }\end{array}$ & 処理薬量 & 調査株数 & $\begin{array}{l}\text { 萎凋株率（\%) } \\
\quad \text { (防除価) }{ }^{\mathrm{b})}\end{array}$ & $\begin{array}{l}\text { 根部発病指数 }{ }^{\mathrm{a})} \\
\quad(\text { 防除価 })\end{array}$ \\
\hline $\begin{array}{l}\text { クロルピクリンくん蒸剤 } \\
(\text { (クロルピクリン : } 99.5 \%)\end{array}$ & $30 \mathrm{l} / 10 \mathrm{a}$ & 27 & $\begin{array}{ll}0 & b^{c)}\end{array}$ & $0.26 b^{d)}(84)$ \\
\hline $\begin{array}{l}\text { ダゾメット粉粒剤 } \\
(\text { ダゾメット：98.0\%) }\end{array}$ & $30 \mathrm{~kg} / 10 \mathrm{a}$ & 27 & $14.8 \mathrm{ab} \quad(41)$ & $1.19 \mathrm{a} \quad(28)$ \\
\hline $\begin{array}{l}\text { カーバムナトリウム塩液剤 } \\
(\text { (カー゙ムムトリウム塩 : } 30.0 \%)\end{array}$ & $60 \mathrm{l} / 10 \mathrm{a}$ & 27 & $11.1 \mathrm{ab} \quad(56)$ & $0.89 \mathrm{ab} \quad(46)$ \\
\hline 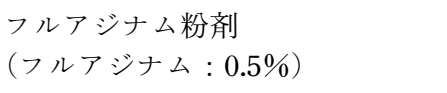 & $30 \mathrm{~kg} / 10 \mathrm{a}$ & 27 & 29.6 a $\quad(0)$ & $1.56 \mathrm{a} \quad(5)$ \\
\hline 無処理 & - & 36 & $25.0 \mathrm{a}$ & $1.64 \mathrm{a}$ \\
\hline
\end{tabular}

a）根部発病指数の算出法は“材料抢よび方法’ に示すとおり.

b）防除価の算出法は“材料扣よび方法’に示すと扣り.

c）同一英文字を付した数值間にはRyanの多重比較検定の結果，5\%水準で有意差がないことを示す．

d）同一英文字を付した数值間には Kruskal-Wallis 検定およびSteel-Dwass の多重比較検定の結果，5\%水準で有意差がないことを 示す.

第 2 表 キュウリホモプシス根腐病に対するクロルピクリンくん蒸剤マルチ畦内処理と全面処理の防除効果

\begin{tabular}{|c|c|c|c|c|c|c|}
\hline \multirow[b]{2}{*}{ 土䁃消毒法 } & \multicolumn{3}{|c|}{2005 年 $(2005-1)$} & \multicolumn{3}{|c|}{2006 年 $(2006-1)$} \\
\hline & 調査株数 & $\begin{array}{c}\text { 萎调株率（\%) } \\
\text { (防除価) b) }\end{array}$ & $\begin{array}{c}\text { 根部発病指数 }{ }^{a)} \\
\text { (防除価） }\end{array}$ & 調査株数 & $\begin{array}{c}\text { 萎调株率（\%) } \\
\text { (防除価） }\end{array}$ & $\begin{array}{c}\text { 根部発病指数 } \\
\text { (防除価) }\end{array}$ \\
\hline 全面処理 & 27 & $\begin{array}{l}\left.0 \mathrm{~b}^{\mathrm{c}}\right) \\
(100)\end{array}$ & $\begin{array}{l}0.26 \mathrm{~b}^{\mathrm{d})} \\
(84)\end{array}$ & 36 & $\begin{array}{c}16.7 \mathrm{ab} \\
(54)\end{array}$ & $\begin{array}{c}1.78 \mathrm{~b} \\
(33)\end{array}$ \\
\hline マルチ畦内処理 & 36 & $\begin{array}{c}0 \mathrm{~b} \\
(100)\end{array}$ & $\begin{array}{c}0.14 \mathrm{~b} \\
(92)\end{array}$ & 36 & $\begin{array}{l}8.3 \mathrm{~b} \\
(77)\end{array}$ & $\begin{array}{l}0.81 \mathrm{c} \\
(70)\end{array}$ \\
\hline 無処理 & 36 & $25.0 \mathrm{a}$ & $1.64 \mathrm{a}$ & 36 & $36.1 \mathrm{a}$ & $2.67 \mathrm{a}$ \\
\hline
\end{tabular}

a）根部発病指数の算出法は“材料执よび方法’に示すと扣り.

b）防除価の算出法は“材料および方法’に示すと扣り.

c）同一英文字を付した数值間には Ryanの多重比較検定の結果，5\%水準で有意差がないことを示す.

d）同一英文字を付した数值間には Kruskal-Wallis 検定および Steel-Dwass の多重比較検定の結果，5\%水準で有意差がないことを 示す. 
した. 無処理の萎调株率は 2005 年では $37.0 \%$ と多発生条件 下，2007 年では $61.1 \%$ と甚発生条件下での検討となった. 消 毒畦幅 $30 \mathrm{~cm}$ （2007 年）では，萎调株率が $47.2 \%$ （防除価 23）と実用的な防除効果は得られなかった. 消毒畦幅 $90 \mathrm{~cm}$ と $60 \mathrm{~cm}$ を比較すると, 2007 年は萎调株の発生および根部の 発病に統計的な有意差は認められなかった. 2005 年は消毒畦
幅 $90 \mathrm{~cm}$ の防除効果が高く，消毒䍜幅 $60 \mathrm{~cm}$ に比べて萎调株 の発生括よび根部の発病が有意に少なかった。萎调株率抢よ び根部発病指数の防除価でみると，2 か年いずれも消毒睢幅 $90 \mathrm{~cm}$ は, 消毒畦幅 $60 \mathrm{~cm}$ に優った.

クロルピクリンくん蒸剂マルチ畦内処理の有効性の評価 第 1 図に消毒畦幅 $60 \mathrm{~cm}$ に打注るルチ畦内処理の萎调株

第 3 表 キュウリホモプシス根腐病に対するクロルピクリンくん蒸剤マルチ畦内処理の消毒畦幅と防除効果

\begin{tabular}{|c|c|c|c|c|c|c|c|}
\hline \multirow[b]{2}{*}{ 土壤消毒法 } & \multirow[b]{2}{*}{ 畦幅 } & \multicolumn{3}{|c|}{2005 年 (2005-2) } & \multicolumn{3}{|c|}{2007 年（2007-1） } \\
\hline & & 調査株数 & $\begin{array}{c}\text { 萎调株率（\%) } \\
\text { (防除価） }\end{array}$ & $\begin{array}{c}\text { 根部発病指数 }{ }^{a)} \\
\quad(\text { 防除価 })\end{array}$ & 調査株数 & $\begin{array}{c}\text { 萎调株率（\%) } \\
\text { (防除価） }\end{array}$ & $\begin{array}{c}\text { 根部発病指数 } \\
\text { (防除価) }\end{array}$ \\
\hline マルチ畦内処理 & $90 \mathrm{~cm}$ & 123 & $\begin{array}{l}0 \quad c^{c)} \\
(100)\end{array}$ & $\begin{array}{l}1.09 \mathrm{c}^{\mathrm{d})} \\
(59)\end{array}$ & 36 & $\begin{array}{c}2.8 \mathrm{~b} \\
(95)\end{array}$ & $\begin{array}{c}0.97 \mathrm{~b} \\
(68)\end{array}$ \\
\hline "1 & $60 \mathrm{~cm}$ & 125 & $\begin{array}{c}11.2 \mathrm{~b} \\
(70)\end{array}$ & $\begin{array}{l}2.26 \mathrm{~b} \\
(14)\end{array}$ & 36 & $\begin{array}{c}11.1 \mathrm{~b} \\
(82)\end{array}$ & $\begin{array}{l}1.36 \mathrm{~b} \\
(56)\end{array}$ \\
\hline "1 & $30 \mathrm{~cm}$ & -e) & - & - & 36 & $\begin{array}{c}47.2 \mathrm{a} \\
(23)\end{array}$ & $\begin{array}{c}2.81 \mathrm{a} \\
(9)\end{array}$ \\
\hline 無処理 & $60 \mathrm{~cm}$ & 100 & $37.0 \mathrm{a}$ & $2.63 \mathrm{a}$ & 36 & $61.1 \mathrm{a}$ & $3.08 \mathrm{a}$ \\
\hline
\end{tabular}

a) 根部発病指数の算出法は“材料扣よび方法’ に示すと打り.

b）防除価の算出法は“材料および方法’ に示すとおり.

c）同一英文字を付した数值間には Ryanの多重比較検定の結果，5\%水準で有意差がないことを示す.

d）同一英文字を付した数値間には Kruskal-Wallis 検定特よび Steel-Dwass の多重比較検定の結果，5\%水準で有意差がないことを 示す.

e) 試験せず.

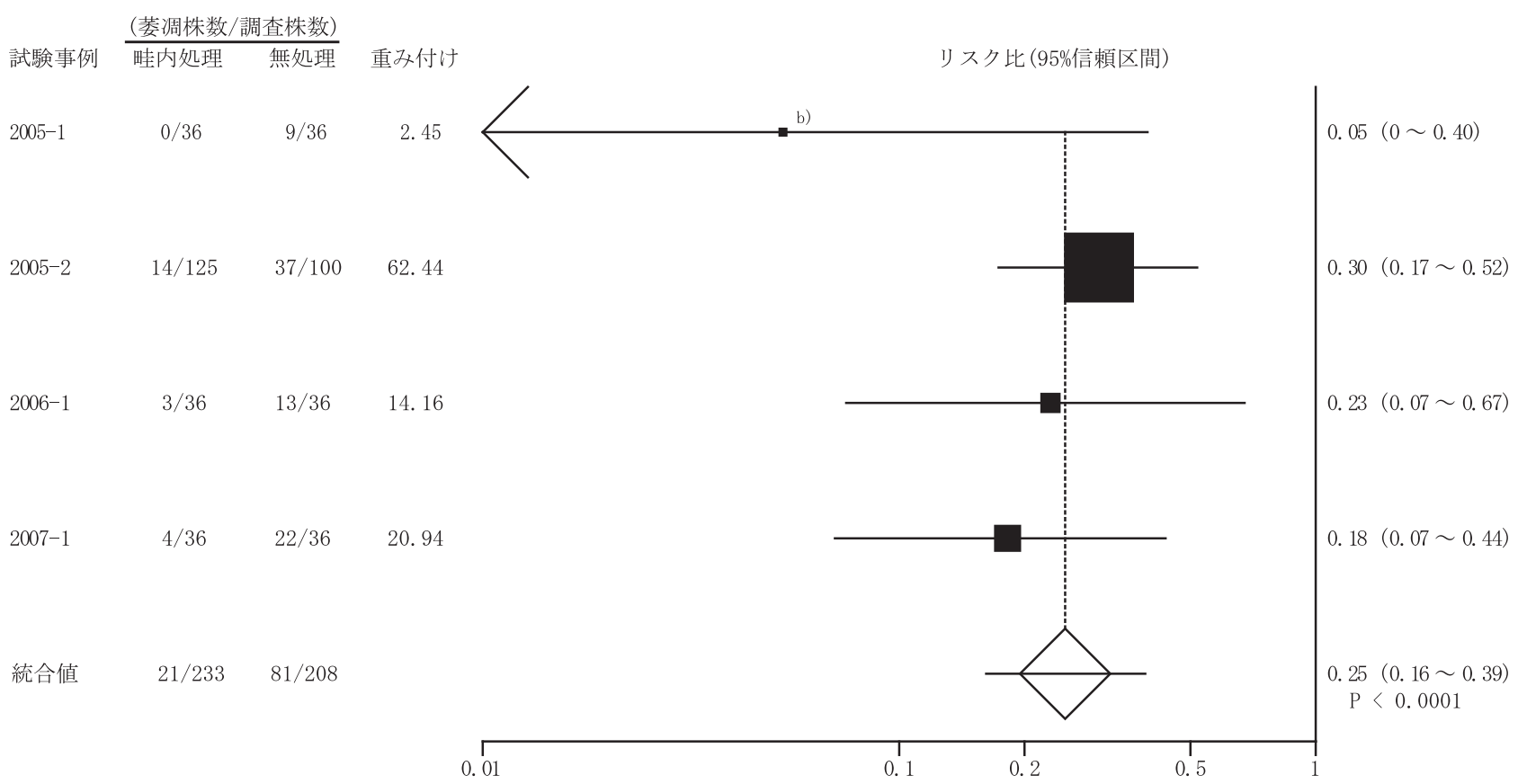

第 1 図 キュウリホモプシス根腐病に対するクロルピクリンくん蒸剤マルチ畦内処理（消毒睢幅 $60 \mathrm{~cm}$ ）の萎凋株発生抑制効果a) a）第 2 表，第 3 表に示す試験成績のらち，供試台木： ‘ひかりパワー’，試験畘幅： $60 \mathrm{~cm}$ とた 4 試験を解析に用いた. b）【はマルチ畦内処理と無処理の萎调株率の割合（リスク比）を，ロの大きさは重み付けの值を，各マーカーの両側の線 は 95\%信頼区間を示す.リスク比の值が 1.0 未満であればその值の分の比率だけ無処理に比べて萎调株の発生率が低いこと を示す。一番下のつは 4 試験の統合リスク比を示す. 


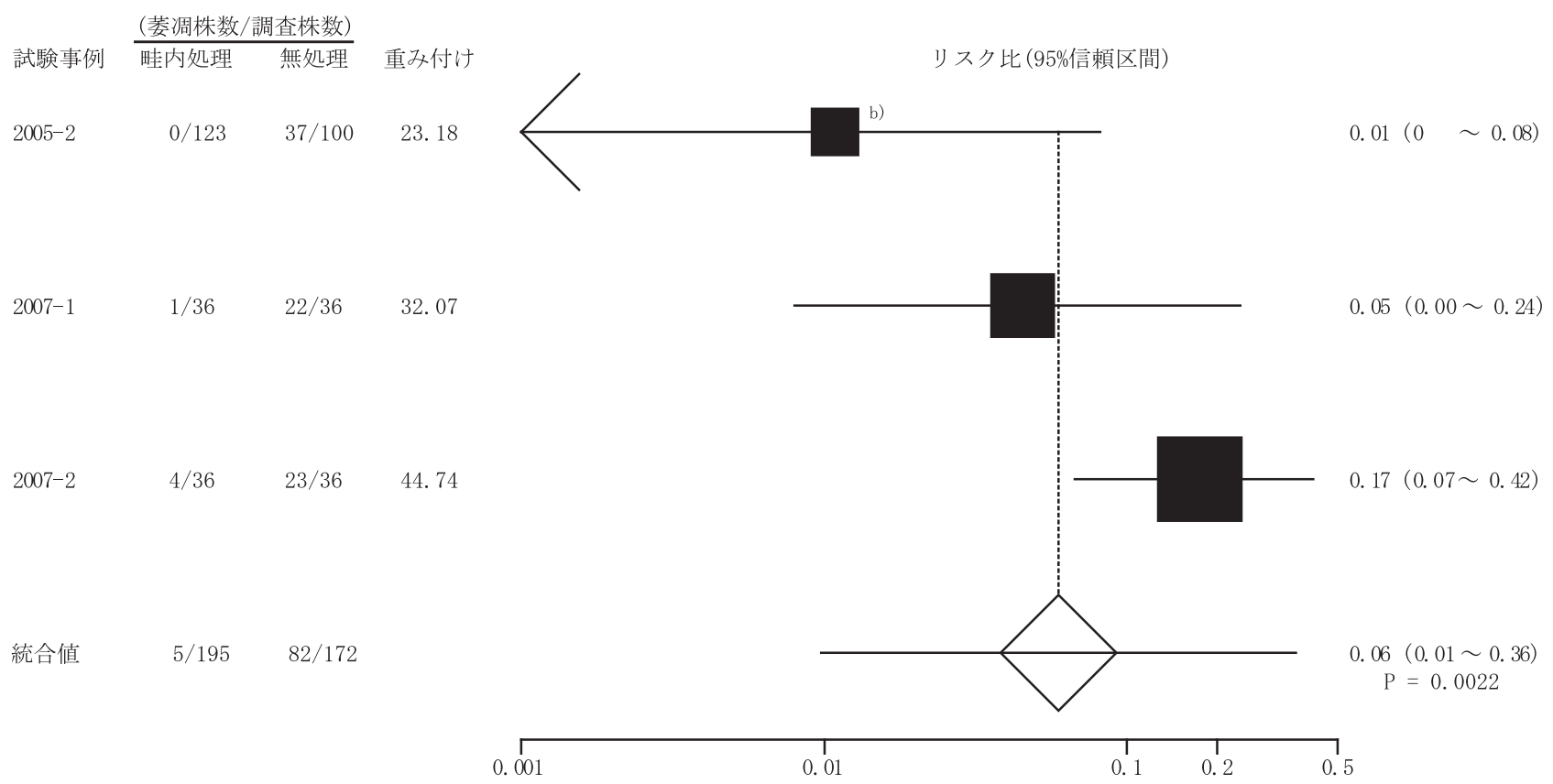

第 2 図 キュウリホモプシス根腐病に対するクロルピクリンくん蒸剤マルチ畦内処理（消毒畦幅 $90 \mathrm{~cm} ）$ の萎调株発生抑制効果 ${ }^{\mathrm{a})}$ a）第 3 表，第 4 表に示寸試験成績のうち，供試台木： ‘ひかりパワー’, 試験畦幅 : $90 \mathrm{~cm}$ とした 3 試験を解析に用いた. b）リスク比の見方は第 1 図を参照のこと.

第 4 表 キュウリホモプシス根腐病に対するクロルピクリンくん蒸剂マルチ畦内処理と抵抗性台木の併用による防除効果

\begin{tabular}{|c|c|c|c|c|c|c|c|c|c|c|}
\hline \multirow[b]{2}{*}{ 土䁃消毒法 } & \multirow[b]{2}{*}{ 台木 } & \multicolumn{3}{|c|}{2005 年 } & \multicolumn{3}{|c|}{2006 年 } & \multicolumn{3}{|c|}{2007 年（2007-2） } \\
\hline & & $\begin{array}{l}\text { 調査 } \\
\text { 株数 }\end{array}$ & $\begin{array}{c}\text { 萎凋株率 } \\
(\%) \\
(\text { 防除価) b) }\end{array}$ & $\begin{array}{l}\text { 根部発 } \\
\left.\text { 病指数 }{ }^{a}\right) \\
\text { (防除価) }\end{array}$ & $\begin{array}{l}\text { 調査 } \\
\text { 株数 }\end{array}$ & $\begin{array}{c}\text { 萎凋株率 } \\
(\%) \\
(\text { (防除価) }\end{array}$ & $\begin{array}{l}\text { 根部発 } \\
\text { 病指数 } \\
\text { (防除価) }\end{array}$ & $\begin{array}{l}\text { 調査 } \\
\text { 株数 }\end{array}$ & $\begin{array}{c}\text { 萎调株率 } \\
(\%) \\
(\text { (防除価) }\end{array}$ & $\begin{array}{c}\text { 根部発 } \\
\text { 病指数 } \\
\text { (防除価) }\end{array}$ \\
\hline マルチ畦内処理 ${ }^{c)}$ & 黒ダネ南瓜 & 27 & $\begin{array}{l}\left.0 \quad b^{d}\right) \\
(100)\end{array}$ & $\begin{array}{l}\left.0 \quad c^{e}\right) \\
(100)\end{array}$ & 36 & $\begin{array}{c}0 \quad b \\
(100)\end{array}$ & $\begin{array}{c}0.75 \mathrm{c} \\
(72)\end{array}$ & 36 & $\begin{array}{c}0 \quad c \\
(100)\end{array}$ & $\begin{array}{c}0.42 \mathrm{~d} \\
(87)\end{array}$ \\
\hline "1 & ひかりパワー & 36 & $\begin{array}{c}0 \quad b \\
(100)\end{array}$ & $\begin{array}{c}0.14 \mathrm{c} \\
(92)\end{array}$ & 36 & $\begin{array}{l}8.3 \mathrm{~b} \\
(77)\end{array}$ & $\begin{array}{c}0.81 \mathrm{c} \\
(70)\end{array}$ & 36 & $\begin{array}{c}11.1 \mathrm{bc} \\
(83)\end{array}$ & $\begin{array}{c}1.53 \mathrm{c} \\
(54)\end{array}$ \\
\hline 無処理 & 黒ダネ南瓜 & 36 & $\begin{array}{c}11.1 \mathrm{ab} \\
(56)\end{array}$ & $\begin{array}{c}0.83 \mathrm{~b} \\
(49)\end{array}$ & 36 & $\begin{array}{c}0 \quad b \\
(100)\end{array}$ & $\begin{array}{c}1.56 \mathrm{~b} \\
(42)\end{array}$ & 36 & $\begin{array}{c}27.8 \mathrm{~b} \\
(57)\end{array}$ & $\begin{array}{c}2.61 \mathrm{~b} \\
(21)\end{array}$ \\
\hline "1 & ひかりパワー & 36 & $25.0 \mathrm{a}$ & $1.64 \mathrm{a}$ & 36 & $36.1 \mathrm{a}$ & $2.67 \mathrm{a}$ & 36 & $63.9 \mathrm{a}$ & $3.31 \mathrm{a}$ \\
\hline
\end{tabular}

a）根部発病指数の算出法は ‘材料扣よび方法’ に示すとおり.

b）“無処理・ひかりパワー’ に対する防除価を“材料扣よび方法”に示すとおり算出した.

c） 2005 年および 2006 年のマルチ畦内処理における処理畦幅は $60 \mathrm{~cm}, 2007$ 年は $90 \mathrm{~cm}$ とした.

d）同一英文字を付した数值間には Ryanの多重比較検定の結果，5\% 水準で有意差がないことを示す．

e）同一英文字を付した数值間には Kruskal-Wallis 検定および Steel-Dwass の多重比較検定の結果，5\%水準で有意差がないことを 示す。

発生抑制効果を示した。 無処理の萎调株率が $25.0 〜 61.1 \%$ といら多〜甚発生条件下での検討となった. 消毒畦幅 $60 \mathrm{~cm}$ に打けるマルチ畦内処理からみた無処理に対する統合リスク 比は 0.25 (95\%信頼区間 : $0.16 〜 0.39$ ）で誤差の範囲を含め て 1.0 未満であった. このことから，消毒畦幅 $60 \mathrm{~cm}$ におけ るマルチ畦内処理の萎调株の発生は, 無処理に比べて有意に 少なく，無処理の萎调株発生率の約 $25 \%$ に抑制されることが
示された. 第 2 図に消毒畦幅 $90 \mathrm{~cm}$ におけるマルチ畦内処理 の萎调株発生抑制効果を示した. 無処理の萎调株率が 37.0 ～ $63.9 \%$ とら多〜甚発生条件下での検討となった。消毒畦 幅 $90 \mathrm{~cm}$ に打けるマルチ畦内処理からみた無処理に対する統 合リスク比は $0.06 （ 95 \%$ 信頼区間：0.01〜0.36）で誤差の範 囲を含めて 1.0 未満であった。 このことから, 消毒畦幅 $90 \mathrm{~cm}$ に打けるマルチ畔内処理の萎调株の発生は, 無処理に比べて 
有意に少なく，無処理の萎调株発生率の約 $6 \%$ に抑制される ことが示された.

\section{クロルピクリンくん蒸剤マルチ畦内処理と抵抗性台木の 併用による防除効果}

第 4 表にマルチ畦内処理と抵抗性台木クロダネカボチャ の併用による防除効果を示した。 ‘無処理・ひかりパワー’の 萎调株率は 2005 年と 2006 年はそれぞれ $25.0 \%$ と $36.1 \%$ と多 発生条件下，2007 年では $63.9 \%$ と甚発生条件下での検討と なったまず，マルチ畦内処理の消毒畦幅 $60 \mathrm{~cm}$ とした 2005 年扮よび 2006 年の試験についてみると'マルチ畦内処理・ 黒ダネ南瓜'と ‘マルチ畦内処理・ひかりパワー'に括いて, 萎调株の発生および根部の発病に統計的な有意差は認めら れなかった，一方で，‘マルチ畦内処理・黒ダネ南瓜’では， 2 か年ともに萎调株の発生はみられず（防除価 100）, 根部発 病指数の防除価も ‘マルチ眭内処理・ひかりパワー' に優っ た. 次に, マルチ畦内処理の消毒畦幅 $90 \mathrm{~cm}$ とした 2007 年 の試験についてみると 'マルチ畦内処理・黒ダネ南瓜'と 'マルチ畦内処理・ひかりパワー'に扔いて，萎调株の発生 に統計的な有意差は認められなかったものの, 根部の発病は ‘マルチ畦内処理・黒ダネ南瓜' で有意に少なかった。萎调 株率打よび根部発病指数の防除価で夕ると, ‘マルチ畦内処 理・黒ダネ南瓜’ は， ‘マルチ畦内処理・ひかりパワー’ に 優った（第 4 表，第 3 図)。なお，“無処理・黒ダネ南瓜”は， 3 か年いずれも萎调株の発生抑制効果が久られたものの, そ の防除価は 56 (2005 年)，100（2006 年），57（2007 年）と 試験年次によって効果に差がみられた。

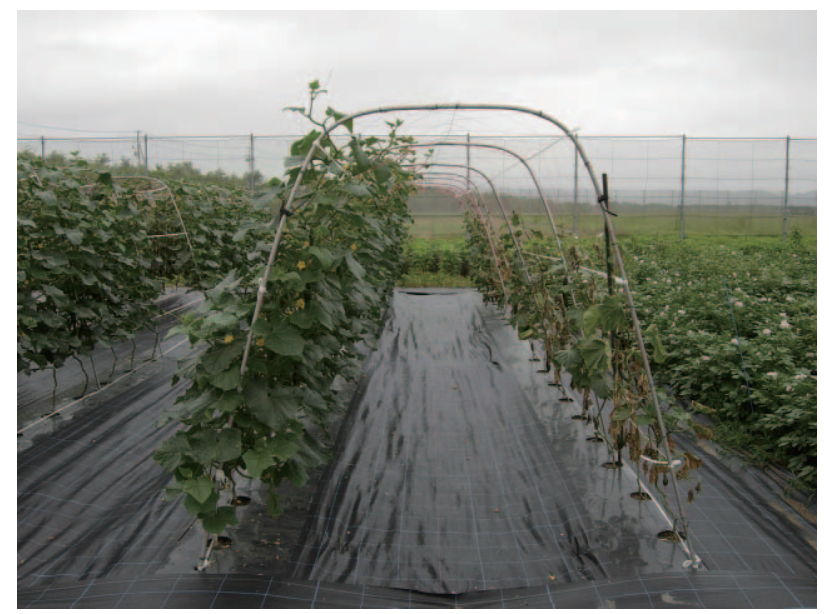

第 3 図 キュウリホモプシス根腐病に対するクロルピクリンく 几蒸剂マルチ畦内処理と抵抗性台木クロダネカボチャ の併用による防除効果 $(2007)$

アーチ左側の畦 : クロルピクリンくん蒸剤マルチ畦内 処理・使用台木 “黑ダネ南瓜”, アーチ右側の畦 : 無処 理・使用台木 ‘ひかりパワー’

\section{考察}

ウリ科野菜のホモプシス根腐病の防除に関する知見は, 施 設栽培のキュウリ（橋本・吉野，1985; 三木ら，2008）やメ ロン（小林ら，1997; 三上，2003），スイカ（宍戸・竹内, 2005）に限られ，その多くは太陽熱を利用した対策が主体と なっている。しかし，東北地方の露地夏秋作型のキュウリ産 地では，太陽熱の活用を前提とした夏期の土壇消毒実施が 不可能である. 本病は污染土䁃にキュウリ苗を定植すると， $2 \sim 3$ 週間で萎调症状を呈する（古屋ら，2006）ことから， 防除法としては土壇消毒が不可欠と考兄られた。 そこで土壤 伝染性の系状菌病害に有効と思われたクロルピクリンくん 蒸剤，ダゾメット粉粒剂，フルアジナム粉剤，カーバムナト リウム塩液剂の土壌消毒剂 4 剂を供試し，本病に対する防除 効果を検討した，その結果，クロルピクリンくん蒸剤は萎调 株の発生抑制効果扔よび根部の発病抑制効果がともに高く, 本病防除薬剂として有望と判断した (第 1 表).

次にクロルピクリンくん蒸剤の処理手法について, 全面処 理とマルチ畦内処理を比較した。 その結果，マルチ畦内処理 は全面処理よりも防除効果の安定性が高く, 高い萎调株発生 抑制効果が得られた（第 2 表）。本剂はマルチ畦内処理が有 効であると考兄られる. マルチ畦内処理で防除効果が高かっ た要因は，作業特性上，ガス抜き耕起を実施しなくても済む ことから, 消毒不十分な深層土塞と表層土壤との混和による 再污染が生じないためと推察された。本法は，栽培時に利用 されるマルチを土壌消毒時の被覆資材として活用できる（福 西，1977）ら光，畦内部の久の部分消毒となるため，単位面 積当たりの必要薬剂量の低減や土壌消毒作業の労力削減も 可能である。また，サッマイモ立枯病（金磯・村井，2007）， カボチャ立枯病（渡辺・大砂，1998），ウド萎ちょら病（白 石ら，1994），イチゴ萎黄病（牧野ら，1986），バレイショそ らか病（中村ら，1985）など栽培時にマルチ被覆を必要とす る作物の土㙵病害対策として本法の有効性が多く報告され ている，よって，本法は本病に対して実用的な効果が期待で きる，普及性が高い防除手段と考光られた。

一方で，マルチ畦内処理は畦の内部の久を消毒する手法で あることから，畦の外側にあたる通路部分は未消毒となる. キュウリの根系は，栽培期間中に通路部分まで進展するた め，畦幅が狭く消毒面積が小さい場合には十分な防除効果が 発揮されないと推察された，そこで，マルチ畦内処理の消毒 畦幅と防除効果について検討した。そ結果，消毒畦幅は慣 行の $60 \mathrm{~cm}$ よりもやや広い $90 \mathrm{~cm}$ とした場合において防除効 果が高かった（第 3 表）。さらに，マルチ畦内処理の消毒畦 幅 $60 \mathrm{~cm}$ とした 4 試験事例，および消毒畦幅 $90 \mathrm{~cm}$ とした 3 
試験事例についてメタアナリシスにより萎凋株の発生抑制 効果を評価した. その結果, マルチ畔内処理の消毒畔幅 $60 \mathrm{~cm}$ では萎调株の発生を無処理の約 $25 \%$ に, 消毒畦幅 $90 \mathrm{~cm}$ では 約 $6 \%$ に抑制可能と判断された（第 1 図，第 2 図).このこと からも, マルチ畦内処理の消毒畘幅 $90 \mathrm{~cm}$ では, 消毒畦幅 $60 \mathrm{~cm}$ に比べて防除効果の安定性が高まると考えられた. 本 病原菌の感染が株元から離れた部位に起こった場合は, 根の 未感染部位の機能は維持され, 萎调症状の発現は抑制される (永坂ら，2007）。消毒畦幅を広くとった場合に防除効果が高 かった要因は, キュウリの株元から未消毒の通路部分までの 距離が確保されたことによる感染時期の遅延により, 萎凋症 状の発現が抑制されたためと推察された. マルチ畔内処理の 防除効果を向上させる手法は, 遮根シート埋め込みによる キュウリ根の污染土壌からの隔離（堀越, 2008）や, 高畔や マルチ裾埋め込みによる簡易的な根域制御（山田・岩舘, 2006）の有効性も報告されている. しかしながら，これらの 手法は作畔手法や栽培体系に大幅な変更を要することから, 広域的な早期普及は困難と考えられた。一方で, 本研究で検 討したマルチ畘内処理の消毒畦幅を広くとる手法は, 現地で の対応が容易であることから普及性は十分高い手法と思わ れる. マルチ畦内処理の処理薬量は, 戒場での作畦間隔によ るものの畦幅 $60 \mathrm{~cm}$ (950 mm 幅マルチ相当）の場合では全 面処理の 30-50\%, 畦幅 $90 \mathrm{~cm}$ (1350 mm 幅マルチ相当）の 場合では全面処理の 50-70\%程度となり, 全面処理に比べる と土壌消毒費用の削減も可能となる. 作睢幅の変更による圃 場作業性や土壌消毒費用必考慮する必要はあるが, 防除効果 の安定性からみると, 本病を対象としたマルチ畦内処理にお いては, 消毒畘幅を慣行よりもやや広い $90 \mathrm{~cm}$ 程度に設定す ることが実用的と考えられる. しかしながら, 本法の防除効 果は完全ではなく, 污染程度が高い圃場などではある程度の 萎调株が発生する恐れが残る。このため, 污染程度が高い圃 場では, マルチ畦内処理のみに頼るのではなく抵抗性台木の 併用など，他の防除技術を組又合わせた総合的防除対策が被 害軽減を図るらえで重要と考えられた.

クロダネカボチャ (C. ficifolia) は, 本病の抵抗性台木とし て有望であるものの, 本台木のみでの防除効果は不安定であ る（橋本・吉野, 1985; 堀越ら, 2003)。そこで, マルチ畘内 処理と抵抗性台木クロダネカボチャの併用による防除効果 について検討した。 その結果, マルチ睢内処理とクロダネカ ボチャ台木の併用では, 消毒畦幅 $60 \mathrm{~cm}$ 抢よび $90 \mathrm{~cm}$ のいず れの試験に拈いて子萎调株の発生がみられず, 根部の発病も 極めて少ないなど顕著な防除効果が得られた（第 4 表, 第 3 図）. 以上から, キュウリホモプシス根腐病の防除対策とし てのマルチ畦内処理は, 単独で用いるよりも, クロダネカボ
チャ台木と併用することでより安定性の高い防除技術とな ることが明らかとなった。しかし，現在のキュウリ栽培は， 流通・販売面での制約によりブルームレス果実の生産が前提 となっている. このため, ブルームを生じるクロダネカボ チャ台木の利用を根幹とする防除技術は, 流通・販売面での 課題が残されている.

本研究では，クロルピクリンくん蒸剤マルチ畦内処理が キュウリホモプシス根腐病の防除法として有効であること, マルチ畦内処理とクロダネカボチャ台木の併用は, これらの 対策を単独で用いるよりも顕著な防除効果が得られること を明らかにした。しかし，クロダネカボチャ台木の広域的な 利用には流通・販売面での課題が残るため, マルチ畔内処理 の防除効果を向上可能な，他の防除対策との組み合わせにつ いても検討が必要であろら. Bacillus subtilis (Ehrenberg) Cohn (Kita et al., 2005) や, Clonostachys rosea (Link:Fr.) Schroers et al. (シノニム Gliocladium roseum Bainier) (Moody and Gindrat, 1977）などいくつかの拮抗微生物は, 本病に対する発病抑 制効果が認められている. マルチ畦内処理とTrichoderma harzianum Rifai の土堙処理の併用によって根の発病抑制が認 められた事例もあり（堀越，私信），マルチ畘内処理と組み 合わせた拮抗微生物の効果的な活用方法についても, 今後の 研究が期待される. 近年, PCR 法を活用した圃場污染程度や 病原菌密度の推定手法の有効性が報告されている（Shishido et al., 2010; 古屋ら，2007）。これらの手法を活用できればマ ルチ畦内処理の実施要否を圃場污染程度に応じて判断する ことも可能になると思われる。 そのためには, 固場污染程度 と本病発生の関係について, 特にも土㙋中での本病原菌の動 態, 宿主への感染やその後の萎调症状にいたる過程など, 本 病原菌に関する生態学的な基礎的知見についても明らかに していく必要がある.

\section{摘 要}

露地夏秋作型のキュウリを対象とした，実用的なホモプシ 又根腐病の防除技術の確立を目的に，有効な土壌消毒薬剤を 選抜するとともに，効果的な処理条件や土壌消毒と抵抗性台 木の併用による防除効果について検討した．クロルピクリン くん蒸剂, ダゾメット粉粒剂, フルアジナム粉剂, カーバム ナトリウム塩液剂の 4 薬剂を供試し, 本病に対する防除効果 を検討した結果, クロルピクリンくん蒸剤の防除効果が高く 本病防除薬剂として有望と判断した. 次に, 本剤の処理手法 について全面処理とマルチ畦内処理を比較した結果, 本剤は マルチ畘内処理が有効であることを明らかにした。ささらに， 本剂のマルチ畦内処理に打ける消毒畦幅について検討した 結果, 消毒畦幅は慣行の畦幅 $60 \mathrm{~cm}$ よりもやや広い $90 \mathrm{~cm}$ と 
した場合に防除効果が高かった. 最後に, 本剂のマルチ畦内 処理と, 本病に一定の抵抗性を示すクロダネカボチャ台木の 併用による防除効果について検討した結果, これらの処理の 併用は，それぞれを単独で用いた場合よりも優れた顕著な防 除効果を示した. このことから, クロルピクリンくん蒸剤、 ルチ畦内処理は, 抵抗性台木クロダネカボチャを併用するこ とでより安定性の高い防除効果が得られると考えられた.

\section{謝辞}

本研究は, 農林水産省の委託事業である「先端技術を活用 した農林水産研究高度化事業（課題番号 1754）」により得ら れた成果である. 本研究の実施にあたって, 共同研究機関各 位には多くのご助言をいただいた，特に，東北農業研究セン タ一福島研究拠点の門田育生博士, 福島県農業総合センター （現福島県庁）の堀越紀夫氏には, 試験設計について有益な ご助言をいただいた。 ここに記して御礼申し上げる.

\section{引用文献}

Bruton, B. D. (1996). Compendium of cucurbit diseases (Zitter, T. A. et al., eds.). p. 19, APS PRESS, Saint Paul MN, USA.

福西 務 (1977). 土壤くん蒸剤のマルチ畦内消毒による土壤病 害防除 I クロルピクリンくん蒸による土畩消毒の効果と 薬害に関する基礎的調査. 徳島農試研報 15: 33-42.

古屋廣光 - 藤 晋一 ・佐藤恵美子 - 村上洋之 ・鈴木倫子 ・ 鈴木 英治・内藤秀樹 (2007). Time Release Fluorescent PCR に よるキュウリホモプシス根腐病菌の土䁃からの検出. 日植 病報 73: 211-212. (講要)

古屋廣光・村上洋之・藤 晋一 - 内藤秀樹 (2006). キュゥリホ モプシス根腐病に打ける土畩伝染源密度と発病株率の関係 (予報)。北日本病虫研報 57:219. (講要)

橋本光司・吉野正義 (1985). カボチャ台キュウリの新病害, ホ モプシス根腐病. 植物防疫 39: 570-574.

堀越紀夫 (2008). 土堙消毒と遮根シートを併用したキュウリホ モプシス根腐病の防除. 今月の農業 52(11): 32-37.

堀越紀夫・藤田祐子・平子喜一 (2003). 露地夏秋キュウリに括 けるホモプシス根腐病の発生. 北日本病虫研報 54: 67-69.

岩舘康哉・勝部和則・猫塚修一 (2006). マルチ畦内土壌消毒と 耐病性台木の組み合わせによるキュウリホモプシス根腐病 の防除効果. 北日本病虫研報 $57: 220$. (講要)

岩舘康哉・山口貴之・藤沢哲也 (2010)。キュウリホモプシス根 腐病抵抗性台木の検索と台木適性. 植物防疫 64: 468-473.

金磯泰雄・村井恒治 (2007). 砂質土䁃の異なる土䁃水分下でマ ルチ畘内処理したクロルピクリン剂のサッマイモ立枯病防 除効果と畦内に打数拡散. 徳島農研報 4: 23-30.

Kita, N., Ohya, T., Uekusa, H., Nomura, K., Manago, M. and Shoda, M. (2005). Biological control of damping-off of tomato seedlings and cucumber Phomopsis root rot by Bacillus subtilis RB14-C. JARQ 39: 109-114.

小林正伸・植草秀敏・折原紀子・宇田川晃 (1997). メロンホモ プシス根腐病の太陽熱消毒と薬剤の併用による防除. 関東
病虫研報 44: 79-81.

牧野孝宏・手塚信夫・鈴井孝仁・中村秀雄 (1986). クロルピク リンの土壤中に打ける拡散とら祖内処理によるイチゴ萎黄 病の防除. 静岡農試研報 31: 23-30.

三上哲壮（2003）。簡易太陽熱処理および太陽熱処理とダゾメッ 卜粉粒剂の併用処理によるメロンホモプシス根腐病防除の 1 事例. 近畿中国四国農研 2:17-20.

三木静恵・漆原寿彦・酒井 宏 (2008). キュウリホモプシス根 腐病に対する土壌還元消毒法の防除効果. 関東病虫研報 55 : $19-20$.

Moody, A. R. and Gindrat, D. (1977). Biological Control of Cucumber Black Root Rot by Gliocladium roseum. Phytopathology 67: 1159-1162.

永坂 厚・門田育生 (2008). 東北地域に打けるキュウリホモプ シス根腐病の発生と防除. 植物防疫 62: 355-358.

永坂 厚・門田育生 (2010). マルチ畧内消毒法を用いたキュウ リホモプシス根腐病の萎调症状の回避対策. 農耕と園芸 65(5): 52-56.

永坂 厚・中嶋美幸・門田育生 (2007)。株元からホモプシス根 腐病菌污染土壇までの距離がキュウリの萎调症状と根系の 発達に与える影響の解析. 根の研究 16: 190. (講要)

中村秀雄・加藤公彦・竹内常雄 (1985). クロルピクリンのマル チ畦内消毒によるバレイショそらか病の防除. 関東病虫研 報 32: 68-69.

宍戸雅宏 (2006). ウリ科野菜のホモプシス根腐病. 植物防疫 60: 583-586.

宾戸雅宏・竹内妙子（2005）， スイカ急性萎调症に対するアン ケート分析と防除対策. 植物防疫 59: 65-68.

Shishido, M., Sato, K., Yoshida, N., Tsukui, R. and Usami, T. (2010). PCR-based assays to detect and quantify Phomopsis sclerotioides in plants and soil. J. Gen. Plant Pathol. 76: 21-30.

Shishido, M., Yoshida, N., Usami, T., Shinozaki, T., Kobayashi, M. and Takeuchi, T. (2006). Black root rot of cucurbits caused by Phomopsis sclerotioides in Japan and phylogenetic grouping of the pathogen. J. Gen. Plant Pathol. 72: 220-227.

白石俊昌・須永文雄・䞇田裕行 (1994). クロルピクリン剂のマ ルチ畦内消毒によるウド萎ちょう病の防除. 群馬農業研究 $\mathrm{D}$ 園芸 8: 35-44.

丹後俊郎 (2002). メタ・アナリシス入門. pp. 61-91, 朝倉書店, 東京.

田代暢哉（2007）。新しい病害虫管理の概念 :-EBC（Evidencebased Control）による防除体系の構築と防除の実際 (44). 今月の農業 51(5): 70-74.

van Kesteren, H. A. (1967). "Black root rot” in cucurbitaceae caused by Phomopsis sclerotioides nov. spec. Neth. J. Plant Pathol. 73: 112-116.

渡辺 健・大砂輝雄（1998）。マルチ畦内土潩消毒によるカボ チャ立枯病の防除. 関東病虫研報 45: 73-75.

Wiggell, P. and Simpson, C. J. (1969). Observations on the control of Phomopsis root rot of cucumber. Plant Pathol. 18: 71-77.

山田修・岩舘康哉（2006）。露地キュウリに打ける睢の形状抒 よび土䁃消毒が生育と萎ちょら症状に及ぼす影響. 東北農 業研究 59: 187-188.

山口貴之・岩舘康哉 (2009). ウリ科植物のキュウリホモプシス 根腐病に対する台木適性. 北日本病虫研報 60: 96-101. 